\title{
Neonatal Rabbit Juxtamedullary Proximal Convoluted Tubule Acidification
}

\author{
Michel Baum \\ Department of Pediatrics, University of Texas Southwestern Medical Center at Dallas, Dallas, Texas 75235
}

\begin{abstract}
The present in vitro microperfusion study examined apical membrane $\mathrm{Na}^{+} / \mathrm{H}^{+}$antiporter and basolateral membrane $\mathrm{Na}\left(\mathrm{HCO}_{3}\right)_{3}$ symporter activity in newborn and adult juxtamedullary proximal convoluted tubules. Proton fluxes were determined from the initial rate of change of intracellular $\mathrm{pH}$ after a change in the luminal or bathing solution, buffer capacity, and tubular volume of newborn and adult tubules. Intracellular $\mathrm{pH}\left(\mathrm{pH}_{\mathrm{i}}\right)$ was measured fluorometrically using the $\mathrm{pH}-$ sensitive dye $\left(2^{\prime}, 7^{\prime}\right)$-bis (carboxyethyl)-(5,6)-carboxyfluorescein (BCECF). Apical $\mathrm{Na}^{+} / \mathrm{H}^{+}$antiporter proton flux, assayed by the effect of sodium removal $(147 \rightarrow 0 \mathrm{meq} / \mathrm{liter})$ on $\mathrm{pH}_{\mathrm{i}}$, was one-third the adult level for the first 2 wk and doubled in the 3rd wk of life. Adult levels were achieved by 6 wk of age. $\mathrm{Na}^{+} / \mathrm{H}^{+}$antiporter activity was not detected on the basolateral membrane of 1-wk-old newborns, indicating that polarity of this transporter was already present. Basolateral membrane $\mathrm{Na}\left(\mathrm{HCO}_{3}\right)_{3}$ proton flux, assayed by the effect of a bath bicarbonate change ( $25 \rightarrow 5 \mathrm{meq} / \mathrm{liter})$ and by a bath sodium change $(147 \rightarrow 0 \mathrm{meq} / \mathrm{liter})$ on $\mathrm{pH}_{\mathrm{i}}$, was $50-60 \%$ of adult values in 1-wk-old newborns. Basolateral membrane $\mathrm{Na}\left(\mathrm{HCO}_{3}\right)_{3}$ proton flux assayed by a bath bicarbonate change ( $25 \rightarrow 5 \mathrm{meq} / \mathrm{liter})$ remained at $50-60 \%$ of adult values for the 1 st mo of life and increased to adult levels by 6 wk of age. This transporter not only plays a role in net acidification, but is an important determinant of cell $\mathrm{pH}$ in newborn juxtamedullary proximal convoluted tubules. (J. Clin. Invest. 1990. 85:499-506.) intracellular $\mathrm{pH} \cdot \mathrm{Na}^{+} / \mathrm{H}^{+}$antiporter $\cdot \mathrm{Na}\left(\mathrm{HCO}_{3}\right)_{3}$ symporter $\bullet$ proton flux
\end{abstract}

\section{Introduction}

Examination of acidification in newborn animals has been complicated by several factors. Clearance studies examine the composite of several nephron segments which may each be at different stages of maturation. These studies do not differentiate differences in transport between superficial and juxtamedullary nephrons (1-3). This problem of nephron heterogeneity encountered in adult animals is accentuated in the developing kidney where there is a centrifugal pattern of nephron maturation (4-8). Furthermore, a change in transport during development may be due to tubular maturation or to developmental changes in the peritubular environment. Both peritubular physical forces and the hormonal milieu which

Address reprint requests to Dr. Baum, Department of Pediatrics, University of Texas Southwestern Medical Center at Dallas, 5323 Harry Hines Boulevard, Dallas, TX 75235.

Received for publication 17 March 1989 and in revised form 2 October 1989.

J. Clin. Invest.

(C) The American Society for Clinical Investigation, Inc.

0021-9738/90/02/0499/08 \$2.00

Volume 85, February 1990, 499-506 may affect transport change during the first weeks of life (9-14). The problems encountered in studying developmental changes in transport are averted by using in vitro microperfusion where a specific nephron segment can be studied under controlled conditions.

In an in vitro microperfusion study, Schwartz and Evan (15) examined bicarbonate and glucose transport and volume absorption during development in juxtamedullary proximal convoluted tubules (PCT). ${ }^{1}$ Volume absorption and bicarbonate transport remained fairly constant for the first 3-4 wk of age at about one-third the adult rate. Between 4 and 6 wk of age there was a dramatic increase in both parameters to values near those seen in adult animals. Glucose transport showed a similar maturational pattern.

Proximal tubule apical proton secretion is primarily via the apical $\mathrm{Na}^{+} / \mathrm{H}^{+}$antiporter (16-21) and bicarbonate exit is primarily via the $\mathrm{Na}\left(\mathrm{HCO}_{3}\right)_{3}$ symporter $(18,22-29)$. Developmental maturation of net bicarbonate transport could be dependent on changes in cellular metabolism as well as $\mathrm{Na}^{+} / \mathrm{H}^{+}$ antiporter, $\mathrm{Na}\left(\mathrm{HCO}_{3}\right)_{3}$ symporter, and $\mathrm{Na}^{+}-\mathrm{K}^{+}$ATPase activity. Using fluorescent measurement of intracellular $\mathrm{pH}\left(\mathrm{pH}_{\mathrm{i}}\right)$, the present in vitro microperfusion study examined $\mathrm{Na}^{+} / \mathrm{H}^{+}$ antiporter activity and basolateral $\mathrm{Na}\left(\mathrm{HCO}_{3}\right)_{3}$ symporter activity in newborn and adult juxtamedullary PCT. The present study demonstrates that the maturation of apical membrane sodium-dependent proton secretion precedes the increase in net bicarbonate transport measured by Schwartz and Evan (15). The present study also demonstrates that polarity of $\mathrm{Na}^{+} / \mathrm{H}^{+}$antiporter activity demonstrated in PCT in adult animals is achieved in newborn juxtamedullary PCT. Surprisingly, basolateral membrane bicarbonate exit is relatively more mature in newborns than apical sodium-dependent proton secretion. This may be due to the fact that the basolateral membrane $\mathrm{Na}\left(\mathrm{HCO}_{3}\right)_{3}$ symporter not only plays a role in net acidification, but is an important determinant of cell $\mathrm{pH}$ in newborn juxtamedullary PCT.

\section{Methods}

Isolated segments of rabbit juxtamedullary PCT were dissected and perfused as previously described $(18,30)$. Briefly, New Zealand white rabbit pregnant does were housed at our institution. Newborn rabbits aged from 1 (1-7 d) to $6 \mathrm{wk}$ (36-42 d) were cared for by their mothers. Adult animals were obtained from the same vendor. Kidneys from animals sacrificed at specific ages were cut in coronal slices. All PCT were dissected from the juxtamedullary cortex and were $0.1-0.3 \mathrm{~mm}$ in length. No late PCT identified by their attachment to proximal straight tubules were employed to avoid problems with axial heterogeneity (18). Individual tubules were dissected in cooled $\left(4^{\circ} \mathrm{C}\right)$ ultrafiltrate-like (UF) solution. This solution was bubbled with $95 \% \mathrm{O}_{2} / 5 \% \mathrm{CO}_{2}$ and

1. Abbreviations used in this paper: $\mathrm{BCECF},\left(2^{\prime}, 7^{\prime}\right)$-bis (carboxyethyl)$(5,6)$-carboxyfluorescein; PCT, proximal convoluted tubule; SITS, 4acetamido-4'-isothiocyanostilbene-2,2'-disulfonate; UF, ultrafiltratelike (solution). 


\begin{tabular}{|c|c|c|c|c|c|c|c|c|c|}
\hline & UF & UF $\bar{s}$ organics & Low-Na, UF & $\begin{array}{c}\text { Low-Na, } \\
\mathrm{UF} \pm \mathrm{NH}_{4} \mathrm{Cl}\end{array}$ & $\mathrm{ONa} \overline{\mathbf{c}}$ organics & ONa s̄ organics & High-Cl-5 $5 \mathrm{HCO}_{3}^{-}$ & $\mathrm{OCl}, \mathrm{UF}$ & $\mathrm{ONa}, \mathrm{OCl}$ \\
\hline & \multicolumn{9}{|c|}{ meq/liter } \\
\hline $\mathrm{Na}^{+}$ & $142^{*}$ & 147 & 40 & 40 & - & - & 142 & 147 & - \\
\hline $\mathrm{K}^{+}$ & 5 & 5 & 5 & 5 & 5 & 5 & 5 & 5 & 5 \\
\hline Choline $^{+}$ & - & - & 100 & 80 & 142.0 & 147.0 & - & - & 25 \\
\hline $\mathrm{NMG}^{+}$ & - & - & - & - & - & - & - & - & 122 \\
\hline $\mathrm{NH}_{4}^{+}$ & - & - & - & 20 & - & - & - & - & - \\
\hline $\mathrm{Ca}^{2+}$ & 1.8 & 1.8 & 1.8 & 1.8 & 1.8 & 1.8 & 1.8 & 9.3 & 9.3 \\
\hline $\mathrm{Mg}^{2+}$ & 1 & 1 & 1 & 1 & 1 & 1 & 1 & 1 & 1 \\
\hline $\mathrm{Cl}^{-}$ & 123.6 & 128.6 & 110.6 & 110.6 & 123.6 & 128.6 & 143.6 & - & - \\
\hline Gluconate $^{-}$ & - & - & - & - & - & - & - & 143.6 & 143.6 \\
\hline $\mathrm{HCO}_{3}^{-}$ & 25 & 25 & 25 & 25 & 25 & 25 & 5 & 25 & 25 \\
\hline $\mathrm{SO}_{4}^{=}$ & 1 & 1 & - & - & 1 & 1 & 1 & 1 & 1 \\
\hline $\mathrm{HPO}_{4}^{=}$ & 1 & 1 & 1 & 1 & 1 & 1 & 1 & 1 & 1 \\
\hline Urea & 5 & 5 & 5 & 5 & 5 & 5 & 5 & 5 & 5 \\
\hline Glu & 5 & - & 5 & 5 & 5 & - & 5 & 5 & 5 \\
\hline Ala & 5 & - & 5 & 5 & 5 & - & 5 & 5 & 5 \\
\hline Hepes & - & - & 25 & 25 & - & - & - & - & - \\
\hline
\end{tabular}

* In solutions where $2 \mathrm{mM}$ amiloride was used, $\mathrm{MgCl}_{2}$ rather than $\mathrm{MgSO}_{4}$ was employed to increase the solubility of amiloride.

had a pH of 7.4. The solutions used are listed in Table I. Tubules were transferred to a $0.2-\mathrm{ml}$ bath chamber and were perfused using concentric glass pipettes. The bathing solution was preheated to $38^{\circ} \mathrm{C}$ and exchanged at a rate of at least $3 \mathrm{ml} / \mathrm{min}$ to maintain a constant bath temperature and $\mathrm{pH}$. In studies where changes were made in the bathing solution in the experimental period, the bath was exchanged at 10 $\mathrm{ml} / \mathrm{min}$. All solutions were adjusted to an osmolality of $295 \mathrm{mosmol} /$ $\mathrm{kg} \mathrm{H}_{2} \mathrm{O}$ with an osmometer (model $3 \mathrm{~W} 2$, Advanced Instruments, Inc., Needham Heights, MA) by adding $\mathrm{H}_{2} \mathrm{O}$ or the predominant salt.

Tubules were initially perfused with an UF solution and bathed in UF solution during a 5-10-min equilibration period. The bathing solution was then changed to one which contained $5 \times 10^{-6} \mathrm{M}$ of the acetoxymethyl derivative of $\left(2^{\prime}, 7^{\prime}\right)$-bis(carboxyethyl)-(5,6)-carboxyfluorescein (BCECF-AM, Molecular Probes, Eugene, OR). This compound is lipid soluble, permeates into cells, and does not fluoresce. Cytoplasmic esterases cleave the ester groups forming the pH-sensitive dye, BCECF. BCECF has four negative charges and leaves the cell slowly (22). The cells were loaded with the dye for 3-6 min and then the bathing solution was changed to the one employed in the control period where the tubules were again equilibrated for at least $5 \mathrm{~min}$ before making any measurements.

Measurement of $p H_{i}$. The fluorescent dye BCECF was used to measure intracellular $\mathrm{pH}$ as has been described previously $(18,22,27$, 30). BCECF has a pH-sensitive excitation maximum at $504 \mathrm{~nm}$ is relatively insensitive to $\mathrm{pH}$ at $436 \mathrm{~nm}$. Peak emission occurs at 526 $\mathrm{nm}$. In the present study excitation was produced alternately at 500 and $450 \mathrm{~nm}$ and emission was measured at $530 \mathrm{~nm}$ (filters from Corion Corp., Holliston, MA). Background was measured before loading and was subtracted from all measurements. Measurements were made using an inverted epifluorescent microscope (Fluovert, E. Leitz, Wetzlar, FRG) at $\times 25$ magnification. A variable diaphragm was placed over the area to be measured. The area ranged from 500 to $2,500 \mu \mathrm{m}^{2}$.

To calculate $\mathrm{pH}$ from the ratio of fluorescence measured at the two excitation wavelengths $\left(F_{500} / F_{450}\right)$, a nigericin calibration curve was performed as previously described $(18,22,27,31)$. There was no developmental difference in the nigericin calibration curve at any pH (6.5, $6.9,7.3,7.7)$ between 1 -wk-old $(n=6)$ and adult juxtamedullary PCT $(n=6)$. The slopes of both curves were 1.67 fluorescent units/pH units.

Acidification rate. After three measurements at 500 and $450 \mathrm{~nm}$, either the lumen or the bath was changed to that used in the experi- mental period. Transporter activity was assayed by continuously monitoring fluorescence at $500 \mathrm{~nm}$, the pH-sensitive wavelength, as either the luminal or bathing solution was changed. The initial rate of change $\left(\mathrm{d} F_{500} / \mathrm{d} t\right)$ was used to calculate the initial rate of change in cell $\mathrm{pH}, \mathrm{dpH} \mathrm{i}_{\mathrm{i}} / \mathrm{d}^{2}$ :

$\frac{\mathrm{dpH}}{\mathrm{d} t}=\frac{\mathrm{d} F_{500} / \mathrm{d} t}{F_{450} \times S}$,

where $F_{450}$ is the $\mathrm{pH}$-insensitive wavelength interpolated from readings before and after the fluid exchange and $S$ is the slope of the $\mathrm{pH}$ calibration curve relating $F_{500} / F_{450}$ to $\mathrm{pH}$. Once a steady state was reached, three measurements at 500 and $450 \mathrm{~nm}$ were made. The solution was then changed to that in the initial period, followed by three additional measurements at 500 and $450 \mathrm{~nm}$.

Buffer capacity. Apparent buffer capacity was measured in a similar fashion to that previously described $(18,27,31)$. Tubules were initially perfused and bathed in low-Na UF solution ( $\mathrm{pH}=7.40$ ). The bathing solution was then rapidly changed to one containing $20 \mathrm{mM} \mathrm{NH}_{3} /$ $\mathrm{NH}_{4}^{+}$(low-Na UF solution, $+\mathrm{NH}_{4} \mathrm{Cl}, \mathrm{pH}=7.40$ ). Because of the large $\mathrm{NH}_{3}$ permeability (32), the cells immediately alkalinize. This is followed by a slower acidification as the cell defends its $\mathrm{pH}_{\mathrm{i}}$. The ratio of the cellular base load to the resulting initial cell $\mathrm{pH}$ change is the buffer capacity:

$\beta=\frac{\Delta\left[\mathrm{NH}_{4}\right]_{\mathrm{i}}}{\Delta \mathrm{pH}_{\mathrm{i}}}$,

where $\Delta \mathrm{pH}_{\mathrm{i}}$ was measured after the addition of $\mathrm{NH}_{3} / \mathrm{NH}_{4}^{+}$. $\left[\mathrm{NH}_{4}^{+}\right]_{\mathrm{i}}$ can be calculated from:

$\left[\mathrm{NH}_{4}^{+}\right]_{\mathrm{i}}=\left[\mathrm{NH}_{4}^{+}\right]_{0} \cdot 10^{\mathrm{pH}_{0}-\mathrm{pH}_{\mathrm{i}}}$.

This equation uses the assumption that the extracellular and intracellular $\mathrm{NH}_{3}$ concentrations are equal. The apparent buffer capacity should be measured when all acidification mechanisms are inhibited. For this reason, $2 \mathrm{mM}$ luminal amiloride was added to inhibit the apical $\mathrm{Na}^{+} / \mathrm{H}^{+}$antiporter and $1 \mathrm{mM}$ 4-acetamido-4'-isothiocyanostilbene-2,2'-disulfonate (SITS) was added to all bathing solutions to inhibit basolateral bicarbonate exit mechanisms $(18,27)$.

2. The $\mathrm{dpH} / \mathrm{d} t$ and proton fluxes are reported as absolute values. 
Table II. Developmental Changes in Juxtamedullary PCT Size

\begin{tabular}{|c|c|c|c|c|c|c|c|}
\hline & 1 & 2 & 3 & 4 & 6 & Adult & \\
\hline Tubules $(n)$ & 40 & 19 & 26 & 23 & 31 & 47 & $F$ test \\
\hline Outer diameter $(\mu m)$ & $40.0 \pm 0.6$ & $35.0 \pm 1.0$ & $37.4 \pm 0.7$ & $38.2 \pm 0.6$ & $47.1 \pm 0.5$ & $47.8 \pm 0.6$ & $67.4 P<0.001$ \\
\hline Inner diameter $(\mu m)$ & $15.3 \pm 0.8$ & $12.0 \pm 0.6$ & $11.8 \pm 0.5$ & $11.8 \pm 0.7$ & $14.1 \pm 0.6$ & $15.4 \pm 0.6$ & $6.4 P<0.001$ \\
\hline $\begin{array}{l}\text { Tubular volume } \\
\left(\times 10^{-10} \text { liters per millimeter }\right.\end{array}$ & $10.65+0.33$ & $8.58+0.48$ & $9.96+0.41$ & $1033+029$ & $1582+034$ & $1607+041$ & $678 P<0001$ \\
\hline
\end{tabular}

Values are means \pm SEM.

Proton flux rates. The proton equivalent flux rate $\left(J_{\mathrm{H}}\right.$, in picomoles per millimeters per minute) is the change in proton flux resulting from an experimental maneuver. It is calculated using the formula:

$J_{\mathrm{H}}=\frac{\mathrm{dpH}}{\mathrm{d} t} \cdot \frac{V}{\mathrm{~mm}} \cdot \beta$,

where $\mathrm{dpH}_{\mathrm{i}} / \mathrm{d} t$ is the initial rate of change in cell $\mathrm{pH}, V$ is the tubular volume in liters per millimeter, and $\beta$ is the buffer capacity. Tubular volume per millimeter was calculated from the measured inner and outer tubular diameter at $\times \mathbf{4 0 0}$ magnification using an eyepiece reticle.

Statistics. The data are expressed as a mean \pm SEM. Analysis of variance and the Student's $t$ test for paired and unpaired data were used to determine statistical significance.

\section{Results}

Juxtamedullary PCT morphometrics. The proton flux induced by a change in the external milieu is in part dependent on the tubular volume per millimeter. The measured inner and outer diameter and the calculated tubular volume of 186 tubules are shown in Table II. The tubular volume of juxtamedullary PCT remains fairly constant during the 1 st mo of life and then increases to near the adult value by 6 wk of age. These results are in excellent agreement with the tubular volumes calculated from the inner and outer diameters reported by Schwartz and Evan (15).

Buffer capacity. Apparent buffer capacity is also a factor influencing the proton flux induced by a change in the external environment. To examine if buffer capacity changes during the course of development, it was measured in 1-wk-old newborns and in adult rabbits in the presence of $\mathrm{CO}_{2}$ and bicarbonate. The initial $\mathrm{pH}$ before $\mathrm{NH}_{3} / \mathrm{NH}_{4}^{+}$addition was $7.24 \pm 0.03$ and $7.32 \pm 0.03$ in newborns and adults, respectively $(P=$ NS). The apparent buffer capacity was $64.3 \pm 14.0$ and $66.4 \pm 9.9 \mathrm{mmol} / \mathrm{liter} \cdot \mathrm{pH}$ unit in newborns $(n=5)$ and adults $(n=6)$, respectively. Thus, buffer capacity was similar in adults and newborns and a constant factor for comparison of proton fluxes in juxtamedullary PCT during development.

Apical membrane sodium-coupled proton secretion. Proximal tubule apical membrane proton secretion is predominantly via the $\mathrm{Na}^{+} / \mathrm{H}^{+}$antiporter (16-21). To examine if $\mathrm{Na}^{+} / \mathrm{H}^{+}$antiporter activity changes during development, juxtamedullary PCT were perfused with a UF solution without organics (UF $\bar{s}$ organics) and bathed in a high-Cl- $5 \mathrm{HCO}_{3}(\mathrm{pH}$ $=6.8$ ) solution containing $1 \mathrm{mM}$ SITS. SITS was present in the bathing solution to inhibit bicarbonate exit across the basolateral membrane. Previous studies have demonstrated that the basolateral membrane transporters are important determi- nants of cell $\mathrm{pH}(20)$. Furthermore, $\mathrm{Na}^{+} / \mathrm{H}^{+}$antiporter activity is $\mathrm{pH}$ dependent and its activity is increased at lower pH's (17). This approach has been used by myself and others to examine $\mathrm{Na}^{+} / \mathrm{H}^{+}$antiporter activity $(18,20)$. There was no glucose and amino acids in the perfusate in these experiments since the reabsorption of these solutes is sodium-coupled and electrogenic. Reabsorption of glucose and amino acids will depolarize the basolateral membrane and affect the rate of bicarbonate exit, an electrogenic process (20). In the experimental period, the perfusate was rapidly changed to one without sodium $(0 \mathrm{Na}$ $\overline{\mathrm{s}}$ organics). The initial rate of change in $\mathrm{pH}_{\mathrm{i}}$ was measured followed by measurements of steady-state $\mathrm{pH}_{\mathrm{i}}$. The luminal perfusate was then changed to one that contained sodium and measurements of steady-state $\mathrm{pH}_{\mathrm{i}}$ were determined to assess recovery.

The steady-state cell pH's are shown in Table III. There was no developmental change in cell $\mathrm{pH}$ under the conditions employed. In each case the cells acidified upon removal of sodium and alkalinized to a value not different from control after sodium was added back to the luminal perfusate. To assess $\mathrm{Na}^{+} / \mathrm{H}^{+}$antiporter activity, the initial rate of change in cell pH upon sodium removal was calculated in each tubule. The results are shown in Fig. 1. There was a constant initial rate of change in cell $\mathrm{pH}$ for the first $2 \mathrm{wk}$ of life in response to a luminal sodium change. By the 3rd wk the rate almost doubled and was not different from that in adult animals.

Since tubular volume also changes during development, the proton flux rate resulting from luminal sodium removal was calculated for each group. ${ }^{3}$ The results are shown in Fig. 2. $J_{\mathrm{H}}$ remained fairly constant at about one-third the adult rate for the first $2 \mathrm{wk}$ of life. $J_{H}$ doubled between the 2 nd and $3 \mathrm{rd}$ wk $(P<0.05)$ and reached a rate not different from that in adults by $6 \mathrm{wk}$. Thus, there is significant maturation of apical sodium-coupled proton secretion in juxtamedullary PCT.

Basolateral bicarbonate exit. Bicarbonate exit across the basolateral membrane of the PCT is predominately via the $\mathrm{Na}\left(\mathrm{HCO}_{3}\right)_{3}$ symporter $(18,22-29)$. Two series of experiments were performed to examine if the rate of bicarbonate exit across the basolateral membrane differed in a 1-wk-old newborn as compared to adults. In the first series of experiments the change in $\mathrm{pH}_{\mathrm{i}}$ in response to a change in bath sodium concentration was examined. Previous studies have demonstrated that bicarbonate exits the cell by a sodium-dependent mechanism $(18,22-29)$. The stoichiometry of the transporter is believed to be $\mathrm{Na}\left(\mathrm{HCO}_{3}\right)_{3}(28,29)$. Thus, lowering bath

3. Since buffer capacity in 1-wk-old and adult juxtamedullary PCT was identical, this value was used in calculation of $J_{H}$ in 2-6-wk-old rabbits. 
Table III. Effect of Luminal $\mathrm{Na}^{+}$Concentration on Steady-State $\mathrm{pH}_{i}$

\begin{tabular}{llll}
\hline & \multicolumn{2}{c}{ Luminal perfusate } & \\
\cline { 2 - 3 } \multicolumn{1}{c}{ Age $(w \mathrm{w})$} & UF $\overline{\mathrm{s}}$ organics & ONa $\overline{\mathrm{s}}$ organics & UF $\overline{\text { s organics }}$ \\
\hline $1(n=7)$ & $7.33 \pm 0.07$ & $7.03 \pm 0.06^{*}$ & $7.31 \pm 0.06$ \\
$2(n=8)$ & $7.24 \pm 0.07$ & $6.91 \pm 0.06^{*}$ & $7.18 \pm 0.07$ \\
$3(n=11)$ & $7.33 \pm 0.03$ & $6.90 \pm 0.05^{*}$ & $7.33 \pm 0.03$ \\
$4(n=10)$ & $7.23 \pm 0.04$ & $6.86 \pm 0.06^{*}$ & $7.22 \pm 0.04$ \\
$6(n=9)$ & $7.31 \pm 0.03$ & $6.98 \pm 0.05^{*}$ & $7.29 \pm 0.03$ \\
Adult $(n=7)$ & $7.33 \pm 0.02$ & $7.04 \pm 0.04^{*}$ & $7.32 \pm 0.03$
\end{tabular}

* Different from control and recovery at $P<0.01$.

sodium should also acidify the cell. To examine the relative rates in newborn vs. adult juxtamedullary PCT, tubules were perfused and bathed with $\mathrm{OCl}-\mathrm{UF}$. The $\mathrm{Na}\left(\mathrm{HCO}_{3}\right)_{3}$ symporter is not dependent on chloride, so for these experiments chloride was removed from the perfusate and bathing solution. During the experimental period the bath sodium was rapidly removed $(0 \mathrm{Na}, 0 \mathrm{Cl})$. Measurements of the initial rate of change in $\mathrm{pH}_{\mathrm{i}}$ and steady-state $\mathrm{pH}_{\mathrm{i}}$ were made and the bathing solution was changed back to the 0Cl-UF in the control period. In these experiments luminal amiloride was not employed since previous studies have demonstrated that measurements of $\mathrm{Na}\left(\mathrm{HCO}_{3}\right)_{3}$ symporter activity is not significantly affected by apical $\mathrm{Na}^{+} / \mathrm{H}^{+}$antiporter activity (18). The adult PCT steadystate $\mathrm{pH}_{\mathrm{i}}$ 's in the control period were significantly lower than in the 1 -wk-old newborn PCT $(7.51 \pm 0.03$ vs. $7.61 \pm 0.03, P$ $<0.05$ ), but this difference was not observed in the recovery period ( $7.57 \pm 0.04$ in adult PCT vs. $7.60 \pm 0.03$ newborn PCT). The magnitude of the $\mathrm{pH}$ change in adult PCT in response to a sodium change was greater in adult PCT than in newborn PCT. Upon sodium removal $\Delta \mathrm{pH}_{\mathrm{i}}$ averaged $0.52 \pm 0.03$ and $0.39 \pm 0.03 \mathrm{pH}$ units in adults and 1 -wk-old newborns, respectively $(P<0.01)$. The initial rate of change in $\mathrm{pH}_{\mathrm{i}}$ and proton equivalent flux induced by a bath sodium change are shown in Fig. 3. The proton equivalent flux in newborn juxtamedullary PCT in response to a bath sodium change was $\sim 50 \%$ of that in adult PCT.

In the second series of experiments examining if the rate of bicarbonate exit in newborns differed from that in adults, tubules were perfused with a UF solution $(\mathrm{pH}=7.4)$ and bathed

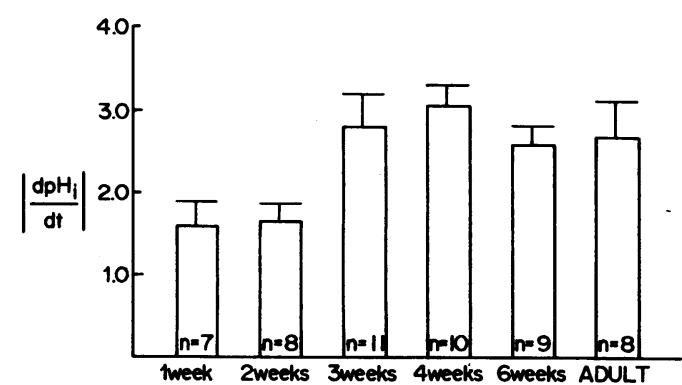

Figure 1. Initial rate of change in intracellular $\mathrm{pH}\left(\mathrm{dpH}_{\mathrm{i}} / \mathrm{d} t\right.$ in $\mathrm{pH}$ units per minute) in response to luminal sodium removal. $(F=3.56$; $P<0.01)$

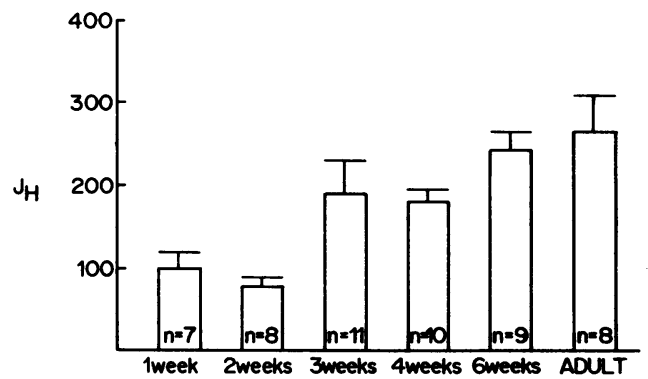

Figure 2. Proton flux $\left(J_{\mathrm{H}}\right.$ in $\left.\mathrm{pmol} / \mathrm{mm} \cdot \mathrm{min}\right)$ in response to luminal sodium removal. $(F=6.68 ; P<0.001)$.

in the same solution in the control period. In the experimental period, the bath bicarbonate concentration was rapidly lowered from 25 to $5 \mathrm{meq} /$ liter (high-Cl- $5 \mathrm{HCO}_{3}, \mathrm{pH}=6.8$ ) and the rate of change of $\mathrm{pH}_{\mathrm{i}}$ was measured. This provided a favorable gradient for bicarbonate to leave the cell resulting in cell acidification. After the $\mathrm{pH}_{\mathrm{i}}$ reached a steady state, the $\mathrm{pH}_{\mathrm{i}}$ was measured and the bathing solution was rapidly changed back to the UF solution used in the control period. In these studies experiments were also performed in 2-, 3-, 4-, and 6-wk-old animals to examine the rate of maturation of this transporter. The results of the steady-state cell pH's are shown in Table IV. There was no significant maturational difference in steadystate $\mathrm{pH}_{\mathrm{i}}$. In each group the initial rate of change in cell $\mathrm{pH}$ upon bicarbonate reduction ( $25 \rightarrow 5 \mathrm{meq} / \mathrm{liter}$ ) was the same as the recovery period $(5 \rightarrow 25 \mathrm{meq} / \mathrm{liter})$. The results were combined and shown in Fig. 4. Surprisingly, there was no significant difference in $\mathrm{dpH}_{\mathrm{i}} / \mathrm{d} t$ at any age. In Fig. 5 the pro-
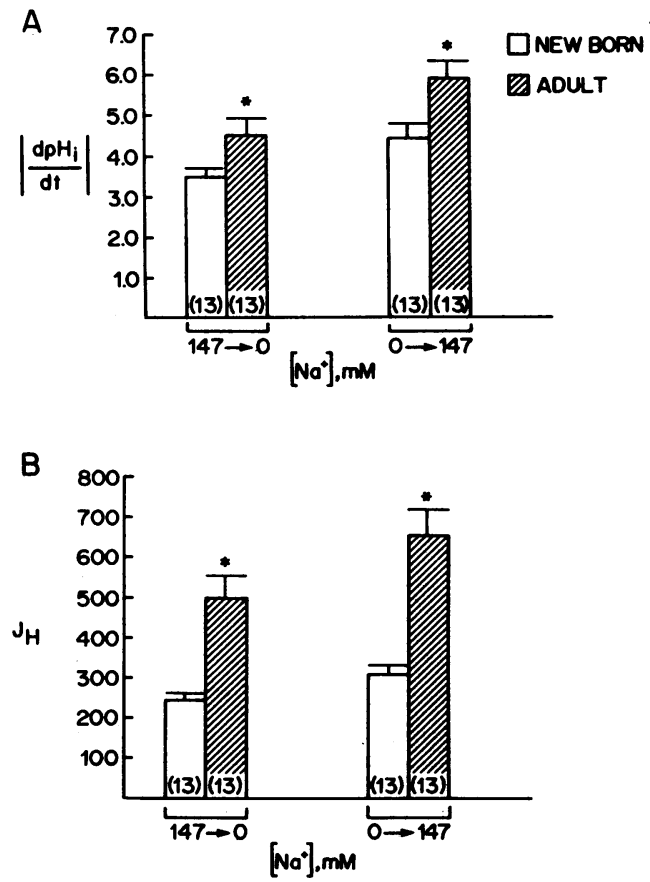

Figure 3. $(A)$ Initial rate of change in cell $\mathrm{pH}\left(\mathrm{dpH}_{\mathrm{i}} / \mathrm{d} t\right.$ in $\mathrm{pH}$ units per minute) in response to a bath sodium change. $\left({ }^{*} P<0.05\right) .(B)$ Proton flux $\left(J_{\mathrm{H}}\right.$ in $\left.\mathrm{pmol} / \mathrm{mm} \cdot \mathrm{min}\right)$ in response to a bath sodium change. $\left({ }^{*} P<0.0001\right)$. 
Table IV. Effect of Bath $\mathrm{HCO}_{3}^{-}$Concentration on Steady-State pH

\begin{tabular}{lccc}
\hline \multicolumn{1}{c}{ Age (wk) } & UF & $\begin{array}{c}\text { Bathing solution, } \\
\text { high-Cl-5HCO}\end{array}$ & UF \\
\hline $1(n=13)$ & $7.51 \pm 0.03$ & $7.11 \pm 0.04^{*}$ & $7.50 \pm 0.03$ \\
$2(n=10)$ & $7.45 \pm 0.02$ & $6.98 \pm 0.03^{*}$ & $7.45 \pm 0.03$ \\
$3(n=8)$ & $7.44 \pm 0.03$ & $7.02 \pm 0.03^{*}$ & $7.45 \pm 0.03$ \\
$4(n=10)$ & $7.51 \pm 0.02$ & $7.05 \pm 0.02^{*}$ & $7.51 \pm 0.02$ \\
$6(n=10)$ & $7.46 \pm 0.02$ & $7.05 \pm 0.03^{*}$ & $7.47 \pm 0.02$ \\
Adult $(n=12)$ & $7.49 \pm 0.02$ & $7.07 \pm 0.02^{*}$ & $7.49 \pm 0.02$
\end{tabular}

* Different from control and recovery at $P<0.01$.

ton equivalent flux rates are shown. The newborn rate of proton secretion resulting from a bath bicarbonate change was $\sim 60 \%$ of that of the adult for the first month of life. $J_{\mathrm{H}}$ reached adult levels by $6 \mathrm{wk}$ of age.

In the above series of experiments, bath sodium removal resulted in cell acidification and readdition resulted in cell alkalinization. These results are consistent with a $\mathrm{Na}\left(\mathrm{HCO}_{3}\right)_{3}$ symporter, but could also be explained by a basolateral $\mathrm{Na}^{+} / \mathrm{H}^{+}$antiporter. While a basolateral $\mathrm{Na}^{+} / \mathrm{H}^{+}$antiporter has not been found in adult PCT $(22,26,27,33)$, the polarization of the $\mathrm{Na}^{+} / \mathrm{H}^{+}$antiporter to the apical membrane may be a maturational event. To examine if the changes in cell $\mathrm{pH}$ resulting from a bath sodium change was due to the $\mathrm{Na}^{+} / \mathrm{H}^{+}$ antiporter or $\mathrm{Na}\left(\mathrm{HCO}_{3}\right)_{3}$ symporter, $2 \mathrm{mM}$ amiloride, an inhibitor of the $\mathrm{Na}^{+} / \mathrm{H}^{+}$antiporter, or $1 \mathrm{mM}$ SITS, an inhibitor of the $\mathrm{Na}\left(\mathrm{HCO}_{3}\right)_{3}$ symporter, was added to the bathing solution of the above adult and 1-wk-old newborn PCT and a second measurement of $J_{\mathrm{H}}$ was made. $J_{\mathrm{H}}$ was $326 \pm 25.3 \mathrm{pmol} /$ $\mathrm{mm} \cdot \mathrm{min}$ in newborn juxtamedullary in the absence of bath amiloride and $408.7 \pm 60.0 \mathrm{pmol} / \mathrm{mm} \cdot \mathrm{min}$ in the presence of 2 $\mathrm{mM}$ bath amiloride $(n=5, \mathrm{NS}) . J_{\mathrm{H}}$ in adult PCT was $677.7 \pm 67.0 \mathrm{pmol} / \mathrm{mm} \cdot \mathrm{min}$ in the absence of amiloride and $590 . \pm 83.9 \mathrm{pmol} / \mathrm{mm} \cdot \mathrm{min}$ after addition of bath amiloride $(n$ $=6$, NS). $J_{\mathrm{H}}$ was $236.2 \pm 25.4 \mathrm{pmol} / \mathrm{mm} \cdot \mathrm{min}$ in newborn juxtamedullary PCT in the absence of bath SITS and 45.1 13.7 $\mathrm{pmol} / \mathrm{mm} \cdot \mathrm{min}$ in the presence of $1 \mathrm{mM}$ bath SITS $(n=6, P$ $<0.001) . J_{\mathrm{H}}$ in adult PCT was $436.6 \pm 71.2 \mathrm{pmol} / \mathrm{mm} \cdot \mathrm{min}$ in the absence of bath SITS and $55.9 \pm 17.5 \mathrm{pmol} / \mathrm{mm} \cdot \mathrm{min}$ after the addition of $1 \mathrm{~mm}$ bath SITS $(n=6, P<0.01)$. Thus, bath amiloride did not significantly inhibit $J_{\mathrm{H}}$. However, bath SITS resulted in an $80-90 \%$ inhibition in $J_{\mathrm{H}}$ in newborn and adult juxtamedullary PCT. These data are consistent with an asymmetrical distribution of the $\mathrm{Na}^{+} / \mathrm{H}^{+}$antiporter in newborn juxtamedullary PCT.

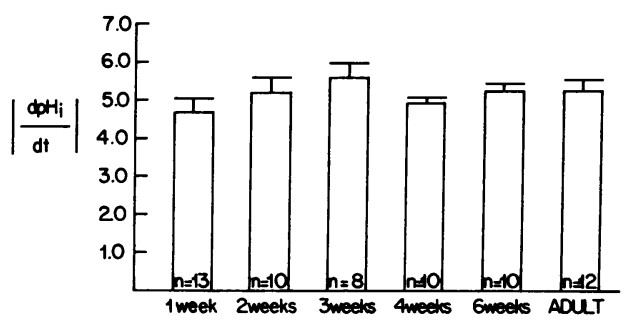

Figure 4. Initial rate of change in cell $\left(\mathrm{dpH}_{\mathrm{i}} / \mathrm{d} t\right.$, in $\mathrm{pH}$ units per minute) in response to a bath bicarbonate change $(F=0.98$; NS).

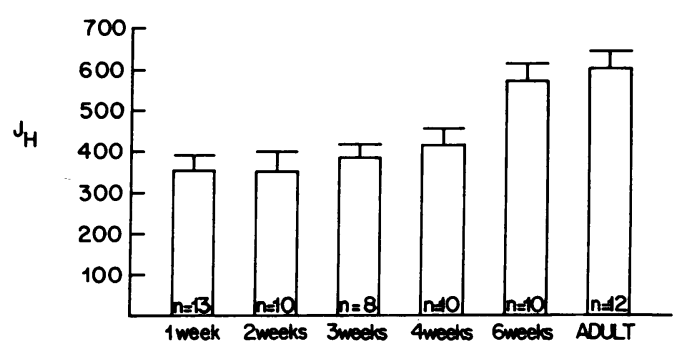

Figure 5. Proton flux $\left(J_{\mathrm{H}}\right.$ in $\left.\mathrm{pmol} / \mathrm{mm} \cdot \mathrm{min}\right)$ in response to a bath bicarbonate change. $(F=7.64 ; P<0.001)$.

Previous developmental studies have provided evidence that maturation of the apical membrane transporters preceded those on the basolateral membrane (34). The present data are consistent with a relatively mature rate of basolateral bicarbonate exit in comparison to apical $\mathrm{Na}^{+} / \mathrm{H}^{+}$antiporter activity. The mechanisms involved in vectorial bicarbonate transport may also be involved in defense of cell $\mathrm{pH}$. To examine if the basolateral membrane was predominantly involved in defense of cell $\mathrm{pH}_{\mathrm{i}}, 1$-wk-old newborn juxtamedullary PCT tubules were perfused and bathed with a UF solution. During the experimental period the luminal perfusate was changed to a high-Cl- $5 \mathrm{HCO}_{3}(\mathrm{pH}=6.8)$ and steady-state cell $\mathrm{pH}$ was measured. During the recovery period, the perfusate was changed to the UF solution. As is demonstrated in Fig. 6, there was no significant change in cell $\mathrm{pH}(n=5)$. Cell $\mathrm{pH}$ was $7.51 \pm 0.06$ in the control period, $7.48 \pm 0.06$ upon luminal acidification and $7.49 \pm 0.05$ in the recovery period. However, when $1 \mathrm{mM}$ SITS was added to the bathing solution to inhibit the basolateral bicarbonate transport mechanisms, the same luminal change in cell $\mathrm{pH}$ produced a large change in cell $\mathrm{pH}$. Cell $\mathrm{pH}$ was $7.35 \pm 0.05$ in the control period and decreased to $7.19 \pm 0.07$ upon luminal acidification $(P<0.01)$. Upon increasing the bicarbonate in the luminal perfusate to $25 \mathrm{meq} / \mathrm{liter}, \mathrm{pH}_{\mathrm{i}}$ increased to $7.36 \pm 0.05(P<0.05) .{ }^{4}$ These data are consistent with the basolateral membrane transporters' being an important determinant of cell $\mathrm{pH}$.

\section{Discussion}

Epifluorescent measurement of intracellular $\mathrm{pH}$ was used to examine transporter activity in newborn and adult juxtamedullary PCT. Apical sodium-coupled proton secretion is approximately one-third the adult value during the first 2 wk of life. The activity doubled by the $3 \mathrm{wk}$ and reached adult values by 6 wk of age. Basolateral $\mathrm{Na}\left(\mathrm{HCO}_{3}\right)_{3}$ symporter activity in 1 -wk-old animals is one-half to two-thirds that measured in adult animals and remains stable for the 1 st mo of life. $\mathrm{Na}\left(\mathrm{HCO}_{3}\right)_{3}$ activity reaches adult levels at $6 \mathrm{wk}$ of age. Basolateral $\mathrm{Na}\left(\mathrm{HCO}_{3}\right)_{3}$ activity is not only involved in net acidification, but is a major determinant of intracellular $\mathrm{pH}$ in newborn juxtamedullary PCT.

The present study measured the initial rate of change in $\mathrm{pH}_{\mathrm{i}}$ to assay transporter activity in juxtamedullary PCT. This assay has been used in vivo and in vitro to examine transporter

4. Bath SITS inhibits $\mathrm{Na}\left(\mathrm{HCO}_{3}\right)_{3}$ activity in the rabbit and rat $\mathrm{PCT}(22$, 27). SITS results in the expected cell alkalinization in the rat $(20,22)$. However, bath SITS does not cause cell alkalinization in the rabbit PCT (27). The reason for this is unclear at present. 


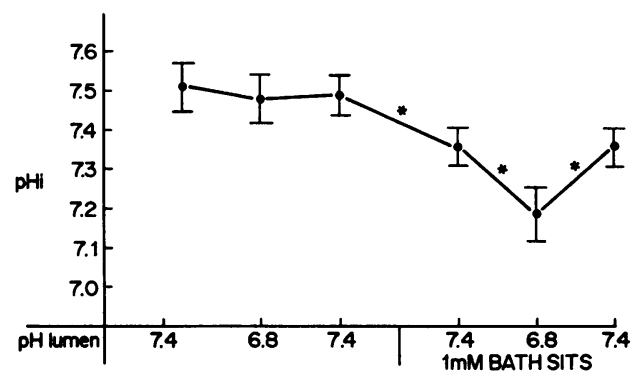

Figure 6. Effect of a luminal $\mathrm{pH}$ change on $\mathrm{pH}_{\mathrm{i}}$ in the absence and presence of $1 \mathrm{mM}$ bath SITS. $\left({ }^{*} P<0.05\right)$

activity in the PCT $(18,35,36)$. While tubular buffer capacity and tubular volume have not been a factor in previous studies, they are potential variables in examining transporter activity during development $(18,35,36)$. If the proximal tubule cellular composition was to change dramatically, buffer capacity could be a factor in comparative measurements of proton flux. Buffer capacity was not different in juxtamedullary proximal convoluted tubules in the 1st wk of life and in adult juxtamedullary PCT. However, tubular volume was a significant factor in these comparisons. Despite the rapid growth of renal size and proximal tubular length during the first month, juxtamedullary PCT volume per millimeter does not change (15). However, tubular volume increases by $50 \%$ to adult values between 4 and 6 wk of age. Tubular volume was calculated from the measured inner and outer PCT diameter. This method assumes that measurements from the tip of the brush border to the basolateral membrane are entirely intracellular and that relative inaccuracies in this measurement are constant during proximal tubule development. This method does not explicitly take changes in surface area to tubular volume into account. Changes in transporter activity during development may be due to a constant density of transporters during maturation with membrane amplification or to an increase in transporter density. Evan et al. (4) have previously demonstrated that there are maturational increases in proximal tubule apical and basolateral membrane surface area during development. The current results are expressed to take only estimated maturational changes in cell volume into account. This allows direct comparison of transporter activity, measured as proton flux in picomoles per millimeter per minute, to previously determined flux data in this segment expressed in similar units (15).

Newborn infants have a lower renal threshold for bicarbonate than adults (37). Since $80 \%$ of bicarbonate is reabsorbed by the proximal tubule, it is likely that the proximal tubule is a factor to explain the lower bicarbonate threshold in newborns. There are several potential reasons for this altered threshold, including tubular immaturity and developmental changes in peritubular physical forces and in the hormonal environment which could affect bicarbonate transport. Previous studies by Schwartz and Evan (15) have clearly demonstrated there is maturation of the juxtamedullary PCT acidifcation during development. The low rates of bicarbonate transport in newborn juxtamedullary PCT could be due to several factors. In the proximal tubule apical proton secretion is predominantly via the $\mathrm{Na}^{+} / \mathrm{H}^{+}$antiporter and bicarbonate exit is via the $\mathrm{Na}\left(\mathrm{HCO}_{3}\right)_{3}$ symporter. Decreased activity of either of these transporters, or of other acidification mecha- nisms such as the proton pump, could explain the lower rates of transport in newborn proximal tubules. The driving force for the $\mathrm{Na}^{+} / \mathrm{H}^{+}$antiporter is a low intracellular sodium generated by the $\mathrm{Na}^{+}-\mathrm{K}^{+}$ATPase. Thus, a limitation of $\mathrm{Na}^{+}-\mathrm{K}^{+}$ ATPase activity or of ATP production could be factors that are responsible for the low rate of bicarbonate transport. Furthermore, each of these factors could be at mature levels but net transport could be low if the bicarbonate permeability were high enough to result in diffusion of transported bicarbonate back into the tubular lumen.

Only one of the above factors has been examined in juxtamedullary PCT. The basolateral membrane surface area is low in newborns, but rises to adult levels by 4 wk (4). Interestingly, however, $\mathrm{Na}^{+}-\mathrm{K}^{+}$ATPase maturation lags behind the maturation in bicarbonate transport in juxtamedullary PCT. In the 1st wk of life, $\mathrm{Na}^{+}-\mathrm{K}^{+}$ATPase activity is one-third that measured in adults (34). The level increases to $60 \%$ of the adult value at $6 \mathrm{wk}$, a time by which bicarbonate transport was comparable to that measured in adults. Only by 7 wk did $\mathrm{Na}^{+}-\mathrm{K}^{+}$ATPase activity reach adult levels (34).

The delayed maturation of the $\mathrm{Na}^{+}-\mathrm{K}^{+}$ATPase activity could be due to its induction by increases in cellular sodium concentration resulting from more rapid maturation of transporters on the apical membrane (34). This induction of $\mathrm{Na}^{+}-\mathrm{K}^{+}$ATPase by increases in apical membrane transport has been described in other epithelia (38). The present study suggests that this may be the case in the proximal tubule. Apical sodium-coupled proton secretion was at about onethird the adult level for the first 2 wk. By 3 wk the level had doubled. This is at a time preceding a significant increase in net acidification suggesting that other factors may limit transport. The cause for the induction of antiporter activity is unknown. As speculation, it may be related to an increase in GFR in juxtamedullary nephrons. In adult rats hyperfiltration leads to an increase in $\mathrm{Na}^{+} / \mathrm{H}^{+}$antiporter activity $(36,39)$. Both uninephrectomy and high-protein diets result in an increase in GFR and brush border membrane vesicle $\mathrm{Na}^{+} / \mathrm{H}^{+}$ antiporter activity (39). Whereas an increase in GFR results in an adaptive increase in antiporter activity in adult animals, it may be an inductive factor in developing nephrons.

In PCT from adult animals the $\mathrm{Na}^{+} / \mathrm{H}^{+}$antiporter is present on the apical, but not the basolateral membrane $(22,26$, $27,33)$. This polarity of transporter distribution increases the efficiency of net acidification. It is possible that this polarization is a maturational event. To examine this issue, sodium was removed from the basolateral membrane in the presence and absence of $2 \mathrm{mM}$ amiloride. There was no inhibition of transport by amiloride. These data are not consistent with a basolateral $\mathrm{Na}^{+} / \mathrm{H}^{+}$antiporter and suggest that at the time of birth the $\mathrm{Na}^{+} / \mathrm{H}^{+}$antiporter is restricted to the apical membrane.

To assess basolateral $\mathrm{Na}\left(\mathrm{HCO}_{3}\right)_{3}$ symporter activity I employed both changes in the bath bicarbonate concentration and sodium concentration. Surprisingly, the rate of change in cell $\mathrm{pH}$ in response to a change in bicarbonate was the same in newborns and adult juxtamedullary PCT. However, there was a small but statistically significant difference in the rate of change in cell $\mathrm{pH}_{\mathrm{i}}$ in response to changes in bath sodium concentration. The $\mathrm{Na}\left(\mathrm{HCO}_{3}\right)_{3}$ symporter activity assessed by a decrease in bath sodium was inhibited by SITS in both newborns and adults. Determination of proton flux rates, which also take buffer capacity and tubular volume into account, 
demonstrated that $\mathrm{Na}\left(\mathrm{HCO}_{3}\right)_{3}$ symporter activity was significantly lower in newborns as assessed by changes in bath bicarbonate and sodium concentration.

In examining data in this nephron segment several striking features are apparent. The rate of both fluid reabsorption and bicarbonate transport in 1-wk-old newborns is one-third that measured in adults (15). In addition, the $\mathrm{Na}^{+}-\mathrm{K}^{+}$ATPase activity in newborn juxtamedullary proximal convoluted tubules is also one-third that in the adult (34). This study demonstrates that $\mathrm{Na}^{+} / \mathrm{H}^{+}$antiporter activity is also one-third that of the adult animal. Interestingly, however, the basolateral membrane $\mathrm{Na}\left(\mathrm{HCO}_{3}\right)_{3}$ symporter activity in newborns was $50-60 \%$ of the value measured in adult juxtamedullary PCT. The maturation of $\mathrm{Na}\left(\mathrm{HCO}_{3}\right)_{3}$ symporter activity was examined by measuring the proton flux in response to a bath bicarbonate change. The rate was constant for the 1 st mo of life. There was a significant increase to adult levels by $6 \mathrm{wk}$ of age. Thus, whereas initiation of maturation of $\mathrm{Na}^{+} / \mathrm{H}^{+}$antiporter activity occurred between 2 and $3 \mathrm{wk}$ of age, an increase in $\mathrm{Na}\left(\mathrm{HCO}_{3}\right)_{3}$ symporter was not measured until several weeks later. It is unclear at present what induces the maturation of this transporter. It is unlikely to be due to intracellular pH changes for this variable remained stable during development.

Acidification mechanisms may not only be operative in net acidification. Cells must be able to defend changes in intracellular pH. In adult rat superficial PCT the basolateral membrane is a more important determinant of cell $\mathrm{pH}$ than transporters on the apical membrane (20). To examine this in newborn juxtamedullary proximal convoluted tubules, the effect of changes in luminal $\mathrm{pH}$ on cell $\mathrm{pH}$ was examined. There was no significant effect on cell $\mathrm{pH}$ despite a $0.6 \mathrm{pH}$ unit change in luminal $\mathrm{pH}$. In the presence of basolateral SITS to inhibit the $\mathrm{Na}\left(\mathrm{HCO}_{3}\right)_{3}$ symporter, there was a $0.17 \mathrm{pH}$ unit change in cell $\mathrm{pH}$. Thus, in the absence of SITS changes in cell $\mathrm{pH}$ were protected by basolateral membrane transporters. This basic and important function may be a factor in the relative maturity of acidification mechanisms on the basolateral membrane.

\section{Acknowledgments}

I am grateful for the technical assistance of Rebecca Archeta and the secretarial assistance of Janell McQuinn.

This work is supported by National Institutes of Health grant DK-38465.

\section{References}

1. Jacobson, H. R. 1979. Characteristics of volume reabsorption in rabbit superficial and juxtamedullary proximal convoluted tubules. $J$. Clin: Invest. 63:410-418.

2. Jacobson, H. R. 1981. Effects of $\mathrm{CO}_{2}$ and acetazolamide on bicarbonate and fluid transport in rabbit proximal tubules. Am. J. Physiol. 240(Renal Fluid Electrolyte Physiol. 9):F54-F62.

3. Jacobson, H. R. 1981. Functional segmentation of the mammalian nephron. Am. J. Physiol. 241(Renal Fluid Electrolyte Physiol. 10):F203-F218.

4. Evan, A. P., V. H. Gattone II, and G. J. Schwartz. 1983. Development of solute transport in rabbit proximal tubule. II. Morphologic segmentation. Am. J. Physiol. 245(Renal Fluid Electrolyte Physiol. 14):F391-F407.

5. Horster, M. 1978. Principles of nephron differentiation. Am. J. Physiol. 4(Renal Fluid Electrolyte Physiol. 5):F387-F393.
6. Larsson, L. 1975. The ultrastructure of the developing proximal tubule in the rat kidney. J. Ultrastruct. Res. 51:119-139.

7. Oliver, J. 1968. Structural status of the kidney at birth. In Nephrons and Kidneys. A Quantitative Study of Development and Evolutionary Mammalian Renal Architectonics. Harper \& Row, New York. 4-116.

8. Welling, L. W., and M. A. Linshaw. 1988. Structural and functional development of outer versus inner cortical proximal tubules. Pediatr. Nephrol. 2:108-114.

9. Arant, B. S., Jr., and W. H. Stephens. 1982. Developmental changes in systemic vascular resistance (SVR) compared with prostaglandins (PG) and angiotensin II(AII) concentrations in arterial plasma in conscious dogs. Pediatr. Res. 16:120A. (Abstr.)

10. Gomez, R. A., K. R. Lynch, R. L. Chevalier, N. Wilfong, A. Everett, R. M. Carey, and M. J. Peach. 1988. Renin and angiotensinogen gene expression in maturing rat kidney. Am. J. Physiol. 254(Renal Fluid Electrolyte Physiol. 23):F582-F587.

11. Felder, R. A., J. C. Pelayo, P. L. Calcagno, G. M. Eisner, and P. A. Jose. 1983. Alpha-adrenoceptors in the developing kidney. $\mathrm{Pe}$ diatr. Res. 17:177-180. (Abstr.)

12. Felder, R. A., L. Schoelkopf, D. P. Sporn, M. Connell, G. M. Eisner, P. L. Calcagno, and P. A. Jose. 1982. Renal beta-adrenergic receptors in the maturing canine. Pediatr. Res. 16:321A. (Abstr.)

13. Horster, M., and H. Valtin. 1971. Postnatal development of renal function: micropuncture and clearance studies in the dog. $J$. Clin. Invest. 50:779-795.

14. Kaskel, F. J., A. M. Kumar, E. A. Lockhart, A. Evan, and A. Spitzer. 1987. Factors affecting proximal tubular reabsorption during development. Am. J. Physiol. 252(Renal Fluid Electrolyte Physiol. 21):F188-F19.

15. Schwartz, G. J., and A. P. Evan. 1983. Development of solute transport in rabbit proximal tubule. I. $\mathrm{HCO}_{3}^{-}$and glucose absorption. Am. J. Physiol. 245(Renal Fluid Electrolyte Physiol. 14):F382-F390.

16. Murer, H., U. Hopfer, and R. Kinne. 1976. Sodium/proton antiporter in brush-border-membrane vesicles isolated from rat small intestine and kidney. Biochem. J. 154:597-604.

17. Aronson, P. S., J. Nee, and M. A. Suhm. 1982. Modifier role of internal $\mathrm{H}^{+}$in activating the $\mathrm{Na}^{+}-\mathrm{H}^{+}$exchanger in renal microvillus membrane vesicles. Nature (Lond.). 299:161-163.

18. Baum, M. 1989. Axial heterogeneity of rabbit proximal tubule luminal $\mathrm{H}^{+}$and basolateral $\mathrm{HCO}_{3}^{-}$transport. Am. J. Physiol. 256(Renal Fluid Electrolyte Physiol. 25):F335-F341.

19. Kinsella, J. L., and P. S. Aronson. 1980. Properties of the $\mathrm{Na}^{+} \mathrm{H}^{+}$exchanger in renal microvillus membrane vesicles. Am. $J$. Physiol. (Renal Fluid Electrolyte Physiol. 7):F461-F469.

20. Alpern, R. J., and M. Chambers. 1986. Cell pH in the rat proximal convoluted tubule-regulation by luminal and peritubular $\mathrm{pH}$ and sodium concentration. J. Clin. Invest. 78:502-510.

21. Warnock, D. G., W. W. Reenstra, and V. J. Yee. 1982. $\mathrm{Na}^{+} / \mathrm{H}^{+}$ antiporter of brush border vesicles: studies with acridine orange uptake. Am. J. Physiol. (Renal Fluid Electrolyte Physiol. 11):F733-F739.

22. Alpern, R. J. 1985. Mechanism of basolateral membrane $\mathrm{H}^{+} / \mathrm{OH}^{-} / \mathrm{HCO}_{3}^{-}$transport in the rat proximal convoluted tubule. $J$. Gen. Physiol. 86:613-636.

23. Akiba, T., R. J. Alpern, J. Eveloff, J. Calamina, and D. G. Warnock. 1986. Electrogenic sodium/bicarbonate cotransport in rabbit renal cortical basolateral membrane vesicles. J. Clin. Invest. 78:1472-1478.

24. Biagi, B. A., and M. Sohtell. 1986. Electrophysiology of basolateral bicarbonate transport in the rabbit proximal tubule. Am. J. Physiol. (Renal Fluid Electrolyte Physiol. 19):F267-F272.

25. Boron, W. F., and E. L. Boulpaep. 1983. Intracellular pH regulation in the renal proximal tubule of the salamander: basolateral $\mathrm{HCO}_{3}^{-}$transport. J. Gen. Physiol. 81:53-94.

26. Grassl, S. M., and P. S. Aronson. $1986 . \mathrm{Na}^{+} / \mathrm{HCO}_{3}^{-}$co-transport in basolateral membrane vesicles isolated from rabbit renal cortex. J. Biol. Chem. 261:8778-8783. 
27. Krapf, R., R. J. Alpern, F. C. Rector, Jr., and C. A. Berry. 1987. Basolateral membrane $\mathrm{Na}$ /Base cotransport is dependent on $\mathrm{CO}_{2} /$ $\mathrm{HCO}_{3}$ in the proximal convoluted tubule. J. Gen. Physiol. 90:833-853.

28. Soleimani, M., S. M. Grassl, and P. S. Aronson. 1987. Stoichiometry of $\mathrm{Na}^{+}-\mathrm{HCO}_{3}^{-}$cotransport in basolateral membrane vesicles isolated from rabbit renal cortex. J. Clin. Invest. 79:1276-1280.

29. Yoshitomi, K., B.-Ch. Burckhardt, and E. Fromter. 1985. Rheogenic sodium-bicarbonate cotransport in the peritubule cell membrane of rat renal proximal tubule. Pfluegers Arch. Eur. J. Physiol. 405:360-366.

30. Baum, M. 1987. Effect of luminal chloride on cell $\mathrm{pH}$ in rabbit proximal tubule. Am. J. Physiol. 254(Renal Fluid Electrolyte Physiol. 23):F677-F683.

31. Roos, A., and W. F. Boron. 1981. Intracellular pH. Physiol. Rev. 61:297-434.

32. Hamm, L. L., D. Trigg, D. Martin, C. Gillespie, and J. Buerkert. 1985. Transport of ammonia in the rabbit cortical collecting tubule. J. Clin. Invest. 75:478-485.

33. Ives, H. E., V. J. Yee, and D. G. Warnock. 1983. Asymmetric distribution of the $\mathrm{Na} / \mathrm{H}$ antiporter in the renal proximal tubule epithelial cell. J. Biol. Chem. 258:13513-13516.

34. Schwartz, G. J., and A. P. Evan. 1984. Development of solute transport in rabbit proximal tubule. III. Na-K-ATPase activity. Am. J. Physiol. 246(Renal Fluid Electrolyte Physiol. 15):F845-F852.

35. Preisig, P. A., and R. J. Alpern. 1988. Chronic metabolic acidosis causes an adaptation in the apical membrane $\mathrm{Na} / \mathrm{H}$ antiporter and basolateral membrane $\mathrm{Na}\left(\mathrm{HCO}_{3}\right)_{3}$ symporter in the rat proximal convoluted tubule. J. Clin. Invest. 82:1445-1453.

36. Alpern, R. J., and P. A. Preisig. 1988. Hyperfiltration Na/H antiporter and basolateral membrane $\mathrm{Na}\left(\mathrm{HCO}_{3}\right)_{3}$ symporter activities in the proximal convoluted tubule. Kidney Int. 35:450A. (Abstr.)

37. Edelmann, C. M., Jr., J. R. Soriano, H. Boichis, A. B. Gruskin, and M. I. Acosta. 1967. Renal bicarbonate reabsorption and hydrogen ion excretion in normal infants. J. Clin. Invest. 46:1309-1317.

38. Petty, K. J., J. P. Kokko, and D. Marver. 1981. Secondary effect of aldosterone on Na-K-ATPase activity in the rabbit cortical collecting tubule. J. Clin. Invest. 68:1514-1521.

39. Harris, C., J. L. Seifter, and B. M. Brenner. 1984. Adaptation of $\mathrm{Na}^{+}-\mathrm{H}^{+}$exchange in renal microvillus membrane vesicles: role of dietary protein and uninephrectomy. J. Clin. Invest. 74:1979-1987. 